\title{
Study of self-efficacy perceptions of Social Studies teacher candidates on educational internet usage
}

\author{
Özkan Akman \\ Department of Social Studies, Gaziantep University, Turkey. \\ Received 16 February, 2016; Accepted 23 March, 2016
}

\begin{abstract}
This study aimed at examining the self-efficacy perceptions of social studies teacher candidates with respect to educational internet use. This research was conducted on a sample of 174 social studies teacher candidates enrolled in Gaziantep University Nizip Faculty of Education. The "Educational Internet Self-Efficacy Scale", developed by Sahin, was used as a data collection tool. The relational scanning method, which is a type of quantitative research techniques, was used in this research. The data obtained from teacher candidates were subjected to independent $t$-tests and one-way variance analyses (ANOVA) using the SPSS $\mathbf{1 8 . 0 0}$ program. The self-efficacy perceptions of the teachers were examined with respect to variables such as gender differences, the place of internet connection, class where education is given, and the Internet usage period. A positive influence was obtained in favor of male teachers with respect to the gender variable among the social studies teachers; however, no significant difference was found with respect to internet connection medium. Significant differences were observed with respect to the classroom, where they get education. The results obtained were compared with other studies. Recommendations are suggested as a result of discussion.
\end{abstract}

Key words: Social Studies teacher candidates, educational internet usage, technology education.

\section{INTRODUCTION}

A rapid increase in internet usage both in Turkey and world has resulted in the studies on the effective, efficient, conscious, and correct usage of the Internet. When referring to the Internet, we mean about 100 million web sites, 30 billion web pages, 1.2 billion registered users, and trillions of commercial activities. Thus the research questions of this study are: How fast we can use such a vital information source for reaching our aims? Does internet provide answers to all of our problems? Are all answers that we seek present on the Internet? How much are search engines assisting in and sufficient for accessing the information we need? Does Internet usage result in loss of time? Can we increase our education portfolio quickly in time? When we speak about internet, most of us consider "search engines" (Eroglu et al., 2011). Therefore how much is that possible to examine the most suitable answers in the results where there are hundreds, thousands, millions, or even billions of answers? When we think that searching such a large number of answers will not be rational in terms of time, it can easily be said that search engines will be insufficient in fast information supply. As a result, a serious progress

E-mail: akmanozkan@hotmail.com.

Authors agree that this article remain permanently open access under the terms of the Creative Commons Attribution License 4.0 International License 
toward niche structuring is observed. It is observed that sectoral, regional search sources and portals are more prominent rather than search engines giving general results such as Google, MSN, Yandex, or Altavista (Isman and Dabaj, 2004).

Nowadays, a rapid change in the usage of the Internet for educational purposes is witnessed. As an inevitable result of this change, the Internet provides users with a variety of means for accessing, using, and disseminating the information. This is the way for establishing a rapid communication with the environment. The integration of new information and communication technologies has transformed the information sources to be effective in academic achievement. For example, the Internet not only significantly impacts all aspects of daily lives of more than 100 million people, but also proves to be advantageous as a tool for accessing communication and information in the field of education. Internet use is common among students; however, this usage is unconscious. Therefore, instructing students about the correct use of the Internet is important for improving their academic performance (Atav et al., 2006; Demirer et al., 2013).

It has been a trend to make existing educational internet usage more efficient rather than giving new technological supports, called Web2.0 (Karaman et al., 2008). However, innovations in Web2.0 technologies have positively impacted each and every field related to education. The usage of these technologies in various fields has led to a change in educational environment. In order to fulfill the learning needs of the contemporary society, renewing tools and equipment in education along with exploring innovations in technology are highly desirable. The use of technologies to facilitate learning has become one of the current subjects for creating an interesting environment for students (Perry and HosackCurlin, 1998; Saeed et al., 2000; Niemz et al., 2005; Bourdeau et al., 2002; Garrett, 2014). The education which does not utilize the technologic opportunities is not able to respond to the present social and individual expectations and the requirements of education. The progress of technology at an advanced level is considered a priority in the present education system (Karasar, 2002).

Pfoeffer (2002) mentioned that at present internet has become an important information source of information for families, students, and teachers. Therefore, many families have an internet subscription for their children. But, the use of the Internet or computer for educational purposes is mostly dependent on family support (Attewel and Battle, 1999). However, in addition to the role of family, the role of teacher and students in the use of the Internet is also important as the students can engage in online activities both inside and outside school. This case requires an establishment of effective cooperation between family, students, and teachers, so that positive aspects of the use of the Internet can be focused on; and an internet usage culture advantageous for children can be created (Altun et al., 2011).

Celen et al. (2011) also pointed that the developmental level of societies will be measured by qualified educational systems that train creative and productive individuals, the level of producing science and technology, and the ability to accommodate with fast development in information and communication technologies. However, Karasar (2004) stated that for the education-teaching tools to be able to keep up to date and fulfill the learning needs, the development and updating of information and communication technologies to meet the expectations of society and individuals are required. FATIH Project, one of the largest educational technology project, aims at effective use of the Internet technology by students (Cevikbas and Cevikbas, 2015). In this study, the educational use of internet is considered important for understanding the self-efficacy perceptions for the educational internet usage of social studies teachers and for taking required measures accordingly with the obtained results.

\section{Purpose of the study}

This study aimed at evaluating the self-efficacy beliefs of social studies teacher candidates for educational internet usage. In order to analyze the purpose, self-efficacy beliefs of the social studies teacher candidates were investigated to determine whether any significant difference exists according to

1. their gender,

2. location for accessing the Internet,

3. grade, and

4. the period of internet use.

\section{METHOD}

\section{Research design}

A comparative-type relational survey model was utilized to conduct this research. The data were collected using a measuring tool from university students selected as a target group of research (Karasar, 2002). In comparison to other research models, a large number of samples are referred to in survey models (Buyukozturk et al., 2008). The existing cases related to the problem were tried to be depicted exactly as they are (Balcı, 2007).

\section{Participants}

The participants of this study were social studies teacher candidates enrolled at Gaziantep University Nizip Faculty of Education, 20152016. A total of 200 social studies education candidates participated in this study. However, 26 participants were excluded from the study due to improperly answered or incomplete questionnaire, reducing the original sample to 174 . Finally, $86(49.4 \%)$ of the participants were men and 88 (50.6\%), women.

\section{Data collection tools}

In this study, Educational Internet Usage Self-Efficacy Beliefs 
Table 1. $t$-Test results for self- efficacy beliefs for educational internet usage with respect to gender.

\begin{tabular}{lcccccc}
\hline Gender status & N & Mean & Std. deviation & df & $\mathbf{t}$ & $\mathbf{p}$ \\
\hline Man & 86 & 87.47 & 23.890 & 172 & 2.308 & 0.022 \\
Woman & 88 & 79.31 & 22.734 & & & \\
\hline
\end{tabular}

Table 2. ANOVA results for self- efficacy beliefs for educational internet usage with respect to the place of internet connection.

\begin{tabular}{|c|c|c|c|c|c|c|c|c|}
\hline Place of internet connection e & $\mathbf{N}$ & Mean & Std. Dev. & The source of variance & Sum of squares & df & $\mathbf{F}$ & p \\
\hline House & 43 & 87.63 & 25.332 & Between groups & 5836.25 & 3 & & \\
\hline School & 47 & 31.48 & 56.421 & Within groups & 87683.4 & 170 & 0517 & 0.101 \\
\hline Internet cafe & 39 & 56.63 & 38.318 & Total & 93519.65 & $1 / 0$ & $3.54 \pi$ & 0.124 \\
\hline Others & 45 & 81.76 & 22.459 & 0 & 0 & 173 & & \\
\hline
\end{tabular}

Scale, developed by Sahin (2009), was used as a data collection tool. In addition to this, a personal information form was used for determining the socio-demographic attributes of candidates such as gender, class, and education level. Based on a five-point Likert type scale, the Self-Efficacy Beliefs Scale for educational internet usage consisted of 28 variables.

\section{Data analysis}

Self-efficacy beliefs for educational internet usage of social studies teacher candidates, obtained from the scale, were compared with respect to several variables. The validity and reliability of the scales was tested as described by Sahin (2009), and Cronbach's alpha reliability coefficient was found to be 0.96 . In the present study, Cronbach's alpha reliability coefficient for this scale was calculated as 0.95 . According to Buyukozturk (2002), the reliability coefficients ranging between 0.80 and 1.00 indicate that items have perfect compliance. The obtained data were analyzed by SPSS (Statistical package for the Social Science) 18.00 program, and independent $t$ tests and one-way analysis of variance (ANOVA) were used to compare the demographic attributes obtained.

\section{FINDINGS}

This section determines whether self-efficacy beliefs of social studies teacher candidates have significant difference in terms of socio-demographic variables. The variable gender was compared using independent group $t$-test to determine any significance difference between the groups, and the results are presented in Table 1.

It can be seen from Table 1 that self-efficacy beliefs of social studies teacher candidates for educational internet usage have significant difference with respect to gender $[t(172)=2.308, p<.0,05]$. It also represents that self efficacy beliefs of men are higher than those of women with respect to the gender variable.

Table 2 shows whether self-efficacy beliefs of social studies teacher candidates have a significant difference with respect to internet connection environment.
It can be seen from Table 2 that there is no significant difference in self-efficacy belief for educational internet usage for social studies teacher candidates with respect to the place of internet connection [ $t(161)=1.547, p>0.05]$.

The self-efficacy beliefs of social studies teacher candidates for educational internet usage were also analyzed for any significant difference with respect to the grade level at which they were being instructed. This variable was analyzed according to independence group ANOVA test. Results related to this analysis are presented in Table 3.

It can be gleaned from Table 3 that self-efficacy beliefs of social studies teacher candidates for educational internet usage present a significant difference with respect to grade level they are instructed $[F=4,811$, $p<0.05]$. Tukey's HSD test was conducted for determining within-group differences. According to Tukey's HSD test, this difference has a mean value of (mean $=77.97$ ) between first grades, (mean $=77.97$ ) between second grades, (mean $=88.15$ ) between third grades, and (Mean $=99.29$ ) between fourth grades. According to data presented in the table, the values between first and second grades are similar, whereas the values between third and fourth grades are higher. It reflects that educational internet usage is at high levels in third and fourth grades

Table 4 shows whether self-efficacy beliefs of social studies teacher candidates have a significant difference with respect to the internet usage period.

As shown in Table 4, there is a significant difference in educational internet usage of social studies teacher candidates with respect to the internet usage period $[F=17.565, p<0.05]$. Tukey's HSD test was conducted for determining the within-group differences. According to the test, this difference is (mean $=68.00$ ) for group using internet between 1 and 3 years, (mean $=80.84$ ) for group using internet between 4 and 6 years, and (mean=92.68) for group using internet for 7 or more years. According to 
Table 3. ANOVA results of self- efficacy beliefs related to the educational internet usage with respect to the grade level.

\begin{tabular}{lcccccccc}
\hline Grade level & N & Mean & Std. Dev. & The source of variance & Sum of Squares & df & $\mathbf{F}$ & $\mathbf{p}$ \\
\hline First grade & 79 & 77.97 & 19.01 & Between Groups & 7541.9 & 3 & & \\
Second grade & 21 & 77.10 & 18.82 & Within Groups & 88829.05 & 170 & & \\
Third grade & 26 & 88.15 & 24.69 & Total & 96370.99 & 173 & 4.81 & .003 \\
Fourth grade & 48 & 92.29 & 28.55 & - & - & - & \\
total & 174 & 83.34 & 23.60 & - & - & - & \\
\hline
\end{tabular}

Table 4. The results of ANOVA for self- efficacy beliefs related to the educational internet usage with respect to the internet usage period.

\begin{tabular}{lccclcccc}
\hline Internet usage year & $\mathbf{N}$ & Mean & Std. Dev. & The source of variance & Sum of square & df & $\mathbf{F}$ & $\mathbf{p}$ \\
\hline 1-3 years & 39 & 68.00 & 19.128 & Between Groups & 16424.352 & 2 & & \\
4-6 years & 56 & 80.84 & 18.191 & Within Groups & 79946.642 & 171 & & \\
7 years and over & 79 & 92.68 & 24.766 & Total & 96370.994 & 173 & 17.565 & .000 \\
Total & 174 & 83.34 & 23.602 & - & - & - & & \\
\hline
\end{tabular}

data represented in the table, it can be seen that selfefficacy for using internet for educational purposes increases along with the increase in the usage period of internet.

\section{DISCUSSION}

This study aimed to evaluate the self-efficacy beliefs of social studies teacher candidates. The comparison of socio-demographic attributes for self-efficacy beliefs of teacher candidates to educational internet usage reveals important findings. In this study, educational internet use self-efficacy beliefs of men compared to that of women were significantly higher. A study conducted by Tuncer and Ogut (2012) with classroom teachers showed that no significant difference with respect to the gender variable was found. In their study related to educational internet usage, Yenilmez et al. (2011) obtained significant results in favor of men with respect to the gender variable. In their study, Kılıc and Coskun (2010) stated that no significant difference related to the gender variable was found. Studies by Akın and Bastug (2005) and Awofala et al. (2015) stated that male students use computer and internet more than the females, but it is generally female students who use internet for educational purposes.

In this study, no significant difference was observed in self-efficacy perception for educational internet usage with respect to internet connection environment. In their study conducted with classroom teachers, Tuncer and Ogut (2012) observed that teacher candidates mostly prefer. Internet café for connection to internet then they prefer their home and school. In their study on internet cafes, Tuncer and Kaysı (2011) mentioned that the use of internet is mostly needed for games and accessing to social share sites. There are many studies indicating that internet cafes are not used for educational purposes (Karadag et al., 2006; Taspınar and Gumus, 2004; Yaylacı, 2000; Karaman, 2010; Jung et al., 2002; Woo and Reeves, 2007).

A significant difference was found in educational internet usage with respect to the grade level. It was observed that self-efficacy perceptions of last-grade students for educational internet usage are high and they use internet with more educational purposes with respect to first-grade students. Tuncer and Ozut (2012) have also reported similar results in their study.

In this study a significant difference was obtained in self-efficacy perceptions of educational internet usage with respect to the usage period. However, the increase in perception of self-efficacy was observed as there is increase in the usage period of internet. According to the research finding, the frequency of using internet does not affect technology usage in educational activities. A study performed by Tuncer and Ozut (2012) with classroom teachers also supports the same idea. Yenilmez et al. (2011) determined that there is a significant difference between self-efficacy perceptions for educational internet usage of teacher candidates; and it was observed that self-efficacy beliefs increase as the usage period of internet increases. The study by Dogruer et al. (2010) also supported this finding, stating that a high relationship was obtained between frequency of use of internet and attitude against internet. Positive attitude toward internet may assist it to be utilized by a teacher for getting information more frequently and to see it as a data source, which they do not fear or have doubts to obtain information. In contrast, there are some studies in literature, which mention that positive attitude for internet is not effective in formation of a positive perception for 
the use of internet for educational purposes (Oral, 2008; Torkzadeh and Van Dyke, 2002; Ekiz et al., 2003; Gunduz and Odabası, 2004; Kuo et al., 2014).

\section{Conclusion}

In Turkey it was observed that internet usage differs according to gender, internet connection environment, age, and usage period. The use of internet and computer has become indispensable tools of life in this technology age. Use of internet by majority of teacher candidates with several purposes is very important for not wasting investments made within the scope of FATIH Project of Ministry of National Education. The use of internet by teacher candidates who will be teachers in future may facilitate popularizing internet in the teaching process. Therefore, it is necessary for teachers to develop certain skills related to technology use.

However, in order to provide a proper and adequate formal training for skillfully using the internet for education and teaching purposes, responsive teacher education programs can be introduced for teacher candidates. Improving the environment for internet use in universities and faculty infrastructure, where students can access internet, will facilitate internet access from school by students and will increase the frequency of internet use.

\section{Conflict of Interests}

The author has not declared any conflicts of interest.

\section{REFERENCES}

Akın M, Bastug A (2005). Erzincan eğitim fakültesi ilköğretim bölümü sınıf öğretmenliği anabilim dalı öğrencilerinin bilgisayar ve internet teknolojilerinden yararlanma düzeylerini belirlemeye yönelik bir ön araştırma. Erzincan Eğitim Fakültesi Dergisi 7(1):47-58.

Altun SA, Kalayci E, Avci U (2011). Integrating ICT at the Faculty Level: A Case Study. Turk. Online J. Educ. Technol. 10(4):230-240.

Atav E, Akkoyunlu B, Sağlam N (2006). Öğretmen adaylarının internete erişim olanakları ve kullanım amaçları. Hacettepe Üniversitesi Eğitim Fakültesi Dergisi 30(30).

Balcı A (1988). Etkili okul. Eğitim ve Bilim, 12(70).

Battle PAJ (1999). Home computers and school performance. Inform. Soc. 15(1):1-10.

Bourdeau L, Chebat JC, Couturier C (2002). Internet consumer value of university students: E-mail-vs.-Web users. J. Retail. Cons. Serv. 9(2):61-69.

Büyüköztürk Ş (2002). Faktör analizi: Temel kavramlar ve ölçek geliştirmede kullanımı. Kuram ve uygulamada eğitim yönetimi 32(32):470-483.

Büyüköztürk Ş, Çokluk Ö, Köklü N (2008). Sosyal bilimler için istatistik.Pegem Yayıncllık, Ankara.

Çelen FK, Çelik A, Seferoğlu SS (2011). Türk eğitim sistemi ve PISA sonuçları. XIII. Akademik Bilişim Konferansı pp. 2-4.

Doğruer N, Menevıs G, EYYAM R (2010). Öğretmen adaylarının internet kullanımı. In International Conference on New Trends in Education and Their Implications pp. 11-13.

Ekiz H, Bayam Y, Ünal H (2003). Mantık Devreleri Dersine Yönelik İnternet Destekli Uzaktan Eğitim Uygulaması. Turk. Online J. Educ. Technol. 2(4):1-8.
Eroglu A, Unlu H, Eroglu I, Yilmaz B. (2011). The review of proficiency of educational Internet usage of physical education teachers and candidate. Selcuk University. J. Phys. Educ. Sport Sci. 13(1):132135.

Gündüz Ş, Odabaşı F (2004). Bilgi çağında öğretmen adaylarının eğitiminde öğretim teknolojileri ve materyal geliştirme dersinin önemi. Turk. Online J. Educ. Technol. 3(1):43-48.

İşman A, Dabaj F (2004). Attitudes of students towards Internet. Turk. Online J. Distance Educ. 5(4).

Jung I, Choi S, Lim C, Leem J (2002). Effects of different types of interaction on learning achievement, satisfaction and participation in web-based instruction. Innovat. Educ. Teach. Int. 39(2):153-162.

Karadağ R, Yılmaz F, Aktay S (2006). Türkiye'de internet kafeler ve ilköğretim. XI. Türkiye'de İnternet Konferansı Bildirileri, 162 p.

Karaman MK (2010). Öğretmen Adaylarının TV ve İnternet Teknolojilerini Kullanma Amaç ve Beklentilerinin Medya Okuryazarlığı Bağlamında Değerlendirilmesi. Uşak Üniversitesi Sosyal Bilimler Dergisi 2010(6).

Karaman S, Yıldırım S, Kaban A (2008). Öğrenme 2.0 yaygınlaşıyor: Web 2.0 uygulamalarının eğitimde kullanımına ilişkin araştırmalar ve sonuçları. XIII. Türkiye'de İnternet Konferansı Bildirileri.

Karasar N (2002). Bilimsel Arastirma Yöntemi [Scientific research methods].Ankara: Nobel.

Karasar Ş (2004). Eğitimde yeni iletişim teknolojileri-internet ve sanal yüksek eğitim. Turk. Online J. Educ. Technol. 3(4):117-125.

Kılıç H, Coskun Y (2010). Öğretmen adaylarının eğitsel amaçlı internet kullanım öz-yeterlik inanç düzeylerinin çeşitli değişkenler açısından incelenmesi. 19. Eğitim Bilimleri Kurultayı, 16-18 Eylül 2010 Uluslar arası Kıbrıs Doğu Akdeniz Üniversitesi, Lefkosa KKTC.

Kuo YC, Walker A, Schroder KEE, Belland BR (2014). Interaction, Internet self-efficacy, and self-regulated learning as predictors of student satisfaction in online education courses. Internet Higher Educ. 20:35-50.

Niemz K, Griffiths M, Banyard P (2005). Prevalence of pathological Internet use among university students and correlations with selfesteem, the General Health Questionnaire (GHQ), and disinhibition. Cyber Psychol. Behav. 8(6):562-570.

Oral B (2008). The evaluation of the student teachers' attitudes toward Internet and democracy. Computer and Educ. 50:437-445.

Perry TT, Anne Perry L, Hosack-Curlin K (1998). Internet use by university students: an interdisciplinary study on three campuses. Internet Res. 8(2):136-141.

Pfoeffer P (2002). Web usability and children: current research and implications for information professionals. Orana 38(2):11.

Saeed H, Asghar M, Anwar M, Ramzan M (2000). Internet use in university libraries of Pakistan. Online Inform. Rev. 24(2):154-160.

Sahin I (2009). Eğitsel internet kullanım öz-yeterliği inançları ölçeğinin geçerliği ve güvenirliği. Selçuk Üniversitesi Sosyal Bilimler Enstitüsü Dergisi 21:461-471.

Taşpınar M, Gümüş Ç (2004). Öğrenmeyi öğrenme kapsamında internet kafelerin eğitsel bir araç olarak kullanımı. XIII. Ulusal Eğitim Bilimleri Kurultayı pp. 6-9.

Torkzadeh G, Van Dyke TP (2002). Effects of training on Internet selfefficacy and computer user attitudes. Comput. Human Behav. 18(5):479-494.

Tuncer M, Kaysı F (2011). Teknik altyapı, sunulan hizmet ve kullanıcı eğilimleri bakımından internet kafelerin değerlendirilmesi (İstanbul ve Elazığ Örneği). 2nd International Conference on New Trends in Education and Their Implications, 27-29 Nisan Antalya.

Tuncer M, Özüt A (2012). Sınıf öğretmeni adaylarının eğitsel Internet kullanımına yönelik öz yeterlik inançları. Turk. Stud. 7(2):1079-1091.

Woo Y, Reeves TC (2007). Meaningful interaction in web-based learning: A social constructivist interpretation. Internet Higher Educ. 10(1):15-25.

Yenilmez K, Turgut M, Anapa P, Ersoy M (2011). İlköğretim matematik öğretmeni adaylarının eğitsel internet kullanımına yönelik öz-yeterlik inançları. 5th International Computer ve Instructional Technologies Symposium, 22-24 September 2011 Fırat University, Elazığ-Turkey. 